Article

\title{
Trends in Population Size of Rare Plant Species in the Alpine Habitats of the Ukrainian Carpathians under Climate Change
}

\author{
Yuriy Kobiv ${ }^{1,2}$ \\ 1 Institute of Ecology of the Carpathians, National Academy of Sciences of Ukraine, Kozelnytska St. 4, \\ 79026 Lviv, Ukraine; ykobiv@gmail.com; Tel.: +38-098-3816919 \\ 2 Botanical Garden of Ivan Franko National University of Lviv, Cheremshyny St. 44, 79014 Lviv, Ukraine
}

Received: 17 April 2018; Accepted: 9 July 2018; Published: 13 July 2018

\begin{abstract}
Population trends in rare alpine plant species in the high-mountain zone of the Ukrainian Carpathians are described with regard to the types of habitats where they occur. Populations of cold-adapted species confined to snowbeds, alpine screes, poorly vegetated rocks, and the highest ridges, as well as mires and springs, are very vulnerable to climate change, while their habitats tend to shrink. The direct impact of warming affects mainly the most cryophilic species. Another driver of changes is climate-induced succession that results in denser vegetation cover and encroachment of more thermophilic plants, which replace low-competitive rare alpine species. Their replacement is largely caused by the loss of open microsites suitable for seed recruitment. However, the climate-driven decrease of snow cover often leads to frost damage to vegetation that provides gaps appropriate for the establishment of many rare species. One of the groups of species that benefit from warming includes rather thermophilic tall herbs that are more common in the subalpine zone but have been actively spreading at higher altitudes lately.
\end{abstract}

Keywords: climate change; alpine species; population; habitat; suitable microsite; Carpathians

\section{Introduction}

Climate changes have considerably affected biota in the past which is best studied for the Quaternary glacial-interglacial alternations during the last 2.5 million years. There is no unanimity on their pace in the past [1], but the velocity of the ongoing climate change is considered as extremely fast [2].

It has been causing significant shifts in the flora and vegetation of the mountain ecosystems all over the world during the last decades. This particularly concerns the upper elevations, where thermal conditions are most crucial for determining the floristic composition of plant communities, as well as the numbers and viability of populations of the specialized species adapted to these harsh environments [3].

That trend totally refers to the Ukrainian Carpathians, which are medium-high mountains where the alpine zone (above $1800 \mathrm{~m}$ a.s.l.) comprises only about $0.1 \%$ of the area [4] and may completely disappear by 2050 [5]. Alpine species occur mainly in the highest massifs: the Chornohora, Svydovets, Marmarosh, and Chyvchyny Mts (Figure 1). There is no subnival zone in the Ukrainian Carpathians, as only a few summits slightly exceed $2000 \mathrm{~m}$ a.s.l. Thus, most cryophilic species (for instance, Cerastium uniflorum, Gentiana frigida, Gentianella tenella, Ranunculus glacialis, and Silene acaulis), which are typical for the highest massifs in the Polish, Slovak, and Romanian Carpathians, are missing in Ukraine. However, other cold-adapted oreophytes that, according to European compendia on ecological values of plants [6-8], are characteristic for the upper alpine zone, do occur in the Ukrainian Carpathians 
or at least have rather recent reliable historical records there (e.g., Agrostis rupestris, Callianthemum coriandrifolium, Cerastium cerastoides, Gentiana nivalis, Luzula spicata, Oreochloa disticha, Salix herbacea, Saussurea alpina, Saxifraga bryoides, S. carpatica).

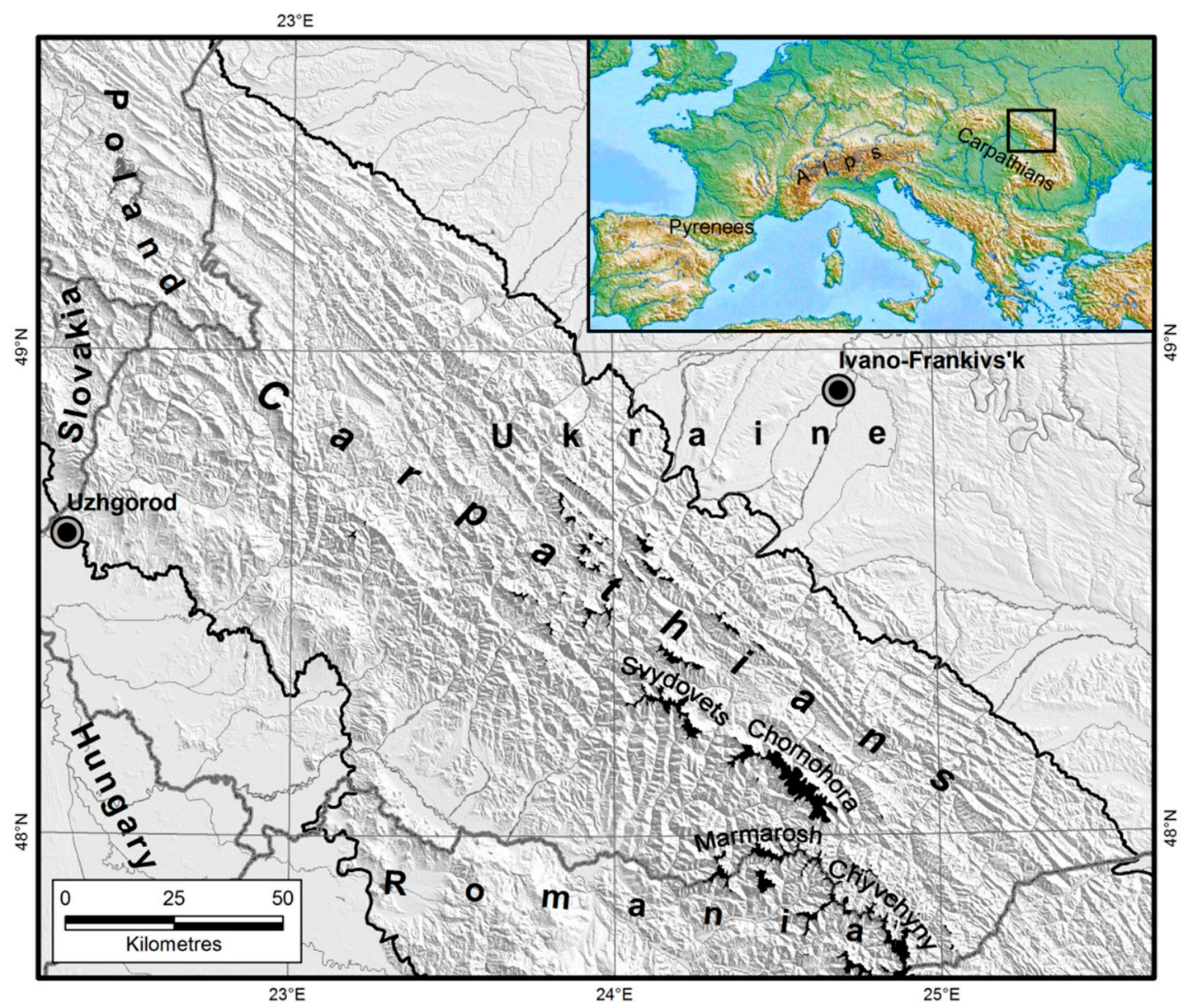

Figure 1. The Ukrainian Carpathians. Location of the high-mountain areas over $1500 \mathrm{~m}$ a.s.l. (black fill) within the Carpathians (thick black lines) and national borders (thick gray lines).

Localities of these cryophiles are restricted mainly to the highest sites of the Ukrainian Carpathians, which, however, refer to the lower limits of the species' altitudinal ranges as it follows from their distribution in other European mountains. Thus, responding to climate change in the Ukrainian Carpathians, most cryophilic species are unable to retreat upslope, which is possible in the higher mountains. Therefore, they are prone to decline and extinction that is particularly worrying for the endemics as it has also been admitted for comparatively low ranges of the outer Alps [9]. In addition to their ecological marginality (i.e., occurrence at the lower limit of the altitudinal range), the alpine species are also geographically peripheral in the Ukrainian Carpathians, where they are confined to the north-eastern edge of their distribution in Central Europe due to location of the target region on the outer side of the Carpathian arc projecting into the vast lowland territories lying between European and Asian high-mountain ranges (Figure 1). Consequently, extinction of cryophilic species in scarce outlying high-mountain "environmental islands" in the region results in noticeable shrinkage of their geographical ranges and biodiversity loss on the all-European scale [10]. Therefore, small alpine patches in the Ukrainian Carpathians are very convenient for monitoring population dynamics of the species whose viability significantly depends on the changing thermal conditions.

The goal of this study was to assess and track the population dynamics of such species with regard to their habitat restriction. In comparison with the studies on shifts in the species' distribution 
and abundance, which have been taking place in the alpine habitats in different mountain systems during the last decades [10-13], monitoring of population parameters of the climate-sensitive species enables the detection of finer changes and trends in their performance. The results of this research are obtained on populations of the model species representing particular types of the alpine habitats and are aimed at better explaining the ongoing species' dynamics in the context of previously revealed long-term changes in their distribution in the Ukrainian Carpathians [10].

\section{Materials and Methods}

The archives of the daily records of the high-mountain Pozhyzhevska Meteorological Station (1450 m a.s.1.) in the Chornohora Mts, Ukrainian Carpathians [14] (in the region where most of the research was carried out) were processed in order to obtain the yearly values of the main variables: snow cover (duration and mean depth), summer air temperature (mean and maximum), and precipitation (annual and summer), which characterize the high-mountain climate and, consequently, shape the alpine biota $[15,16]$. Corresponding charts were built to reveal the trends possibly referring to climate change (Figure 2) which could help to explain the dynamics of populations and habitats of the studied species.
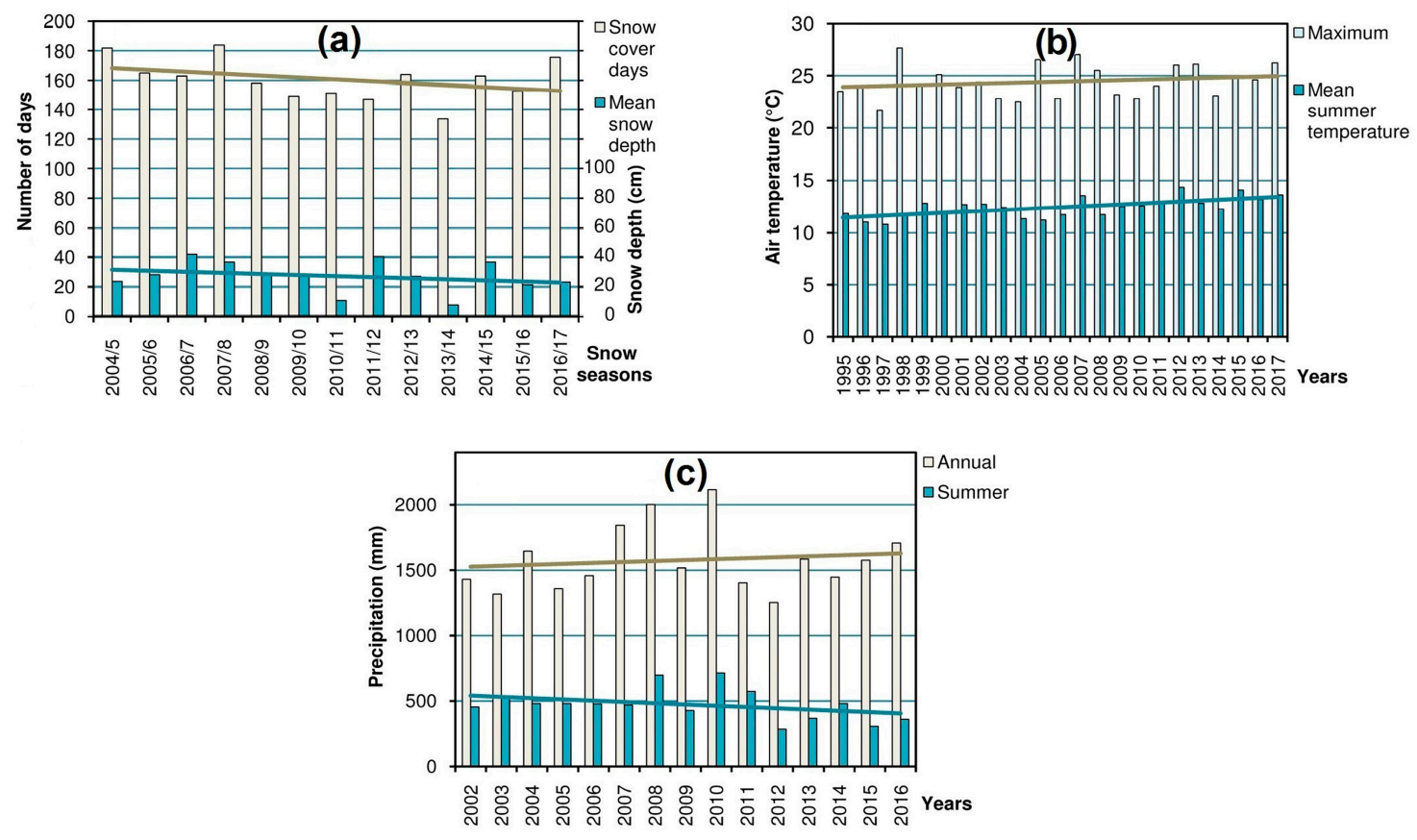

Figure 2. Dynamics of the main climatic variables: (a) snow cover (duration and mean depth); (b) summer air temperature (mean and maximum); (c) precipitation (annual and summer) and their trend lines according to the data from the Pozhyzhevska Meteorological Station in the Chornohora Mts [14].

The species were considered as rare according to the compendium compiled by Malinovski et al. [17]. Almost all of them are included in the "Red Data Book of Ukraine" [18]. While selecting target species, special attention was paid to the high-mountain plants that proved to be susceptible to global warming in the other mountain systems of Europe [12,15].

The target species were classified according to their habitat preferences, i.e., occurrence predominantly in the following types of habitats: snowbeds, screes, rocks, ridges, swards, tall-herb communities, dwarf-shrub heaths, springs, and mires [19,20].

Snowbeds harbor chionophilous communities (class Salicetea herbaceae) with low-statured, poorly competitive cryophilic species adapted to short (2-2.5 month) vegetative periods and confined 
to mossy or barren patches, for instance, Cerastium cerastoides, Salix herbacea, Saxifraga carpatica, and Veronica alpina.

Alpine gravel screes are formed by erosion due to snowpack shift on steep slopes or hollows. These scarce in the Ukrainian Carpathians localities are almost deprived of vegetation and provide suitable habitats for low-competitive glareophytic cold-dwelling r-strategists that need barren microsites, such as Cardaminopsis neglecta, Leontodon pseudotaraxaci, Oxyria digyna, Saxifraga oppositifolia, and Trifolium badium, as well as more thermophilic Biscutella laevigata and Rumex scutatus, which are restricted mostly to communities that belong to the alliance Androsacion alpinae.

Rocky localities represent different saxicolous communities where the following high-mountain rare species occur: Agrostis rupestris, Antennaria carpatica, Carex rupestris, Draba siliquosa, Erigeron alpinus, E. atticus, Hedysarum hedysaroides, Lloydia serotina, Primula minima, Saussurea alpina, and Thlaspi dacicum.

The ridge habitats are also characterized by the rocky substrate. Their hypsometric position depends on the altitude of a particular mountain range, where they are restricted to its uppermost unsheltered sites exposed to the lowest temperatures. Such localities may provide microrefugia for the most specialized cryophilic species (for instance, Dryas octopetala, Gentiana nivalis, Luzula spicata, Oreochloa disticha, Saxifraga bryoides, Veronica aphylla, and V. bellidioides).

The swards are low-grass tussock communities on rather flat areas [20]. The following rare species occur there: Callianthemum coriandrifolium, Polygonum viviparum, Saxifraga adscendens, Senecio carpathicus, and Thlaspi kovatsii.

Tall-herb and tall-grass communities of the class Mulgedio-Aconitetea are more common in the subalpine zone. They harbor some rare taxa (Achillea lingulata, Aconitum moldavicum subsp. hosteanum, Bupleurum longifolium subsp. vapincense, Campanula serrata, Centaurea kotschyana, Delphinium elatum subsp. nacladense, Dianthus speciosus, Festuca carpatica, Gentiana punctata, Heracleum carpaticum, H. palmatum, and Pedicularis hacquetii) which occur mostly on moist humus-rich soils in small depressions and grooves between rocks or at their bottom.

Alpine and subalpine dwarf-shrub heaths belong to the class Loiseleurio-Vaccinietea. They are dominated by common (Vaccinium myrtillus, V. gaultherioides, V. vitis-idaea) or rare (Loiseleuria procumbens, Rhododendron myrtifolium) ericaceous species.

The rare species which occur in the mires, springs, and riparian sites are Carex bicolor, Epilobium anagallidifolium, Pedicularis oederi, P. verticillata, Saxifraga aizoides, and Swertia perennis subsp. alpestris.

One or two case study species were chosen to represent each type of these habitats. Trends in population size of 10 selected species were monitored between 1997 and 2017 on permanent plots (Figure 3). Periods between their resurveys might be uneven and dependent on the opportunity to visit a locality. Location and size of the permanent plots are listed in Table 1 . The area and spatial dispatch of permanent plots depended on the population spatial characteristics and homogeneity of the species dispersal and were designed in order to obtain adequate data variation [21]. The density of adult individuals or ramets (depending on the life form) was estimated on $10.0 \times 0.5,12.5 \times 0.5$, or $20 \times 1 \mathrm{~m}$ line transects or rectangular plots subdivided into 0.25 or $1.0 \mathrm{~m}^{2}$ quadrats. Sample size in each studied locality numbered at least 20 quadrats. If the properties of substratum (e.g., solid rock, gravel scree) or snowpack shift did not allow for the establishment of permanent transects, then firm marking rods were pegged to fix the quadrat frames during next resurveys [22].

If the density of seedlings of the studied species was significantly higher than in adult individuals, the former parameter was estimated separately on smaller $(0.2 \times 0.2 \mathrm{~m})$ quadrats [23].

When appropriate, e.g., in small populations (such as Erigeron atticus or Veronica bellidioides) their complete census was estimated.

In Figure 3, the error bars in charts show $90 \%$ confidence intervals of the mean value of a parameter computed using $t$ statistic for corresponding sample size [23] by means of the STATISTICA software package. 

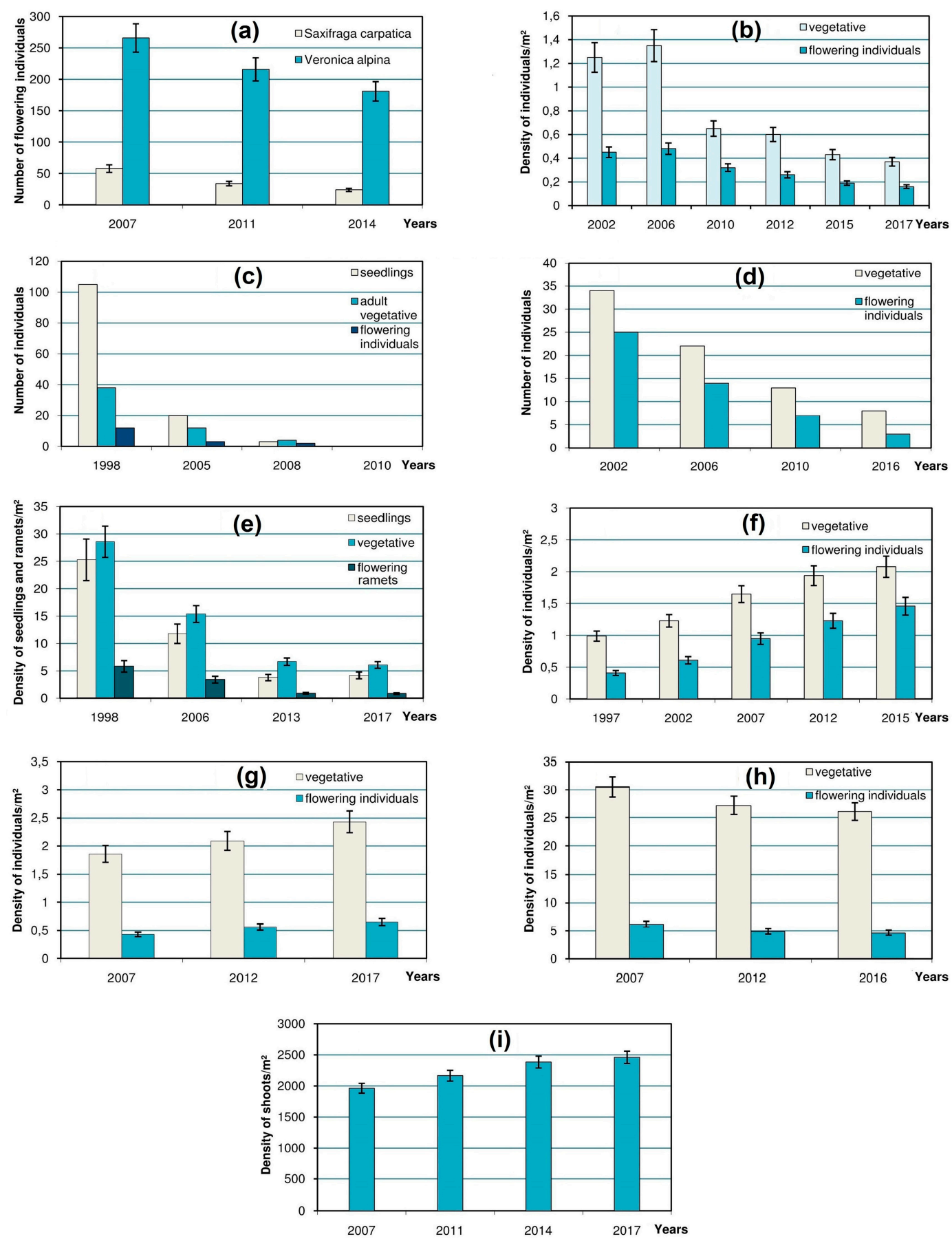

Figure 3. Dynamics of population size of the studied alpine rare species in different types of habitats in the Ukrainian Carpathians: (a) Saxifraga carpatica and Veronica alpina in their snowbed habitat (census of flowering individuals); (b) Cardaminopsis neglecta in its scree habitat (density of vegetative and flowering individuals); (c) Erigeron atticus in its rocky habitat (census of seedlings, vegetative, and flowering individuals); (d) Veronica bellidioides in its ridge habitat (census of vegetative and flowering individuals); (e) Swertia perennis subsp. alpestris in its mire habitat (density of seedlings, vegetative, and flowering ramets); (f) Achillea lingulata in its tall-herb habitat in the Chornohora Mts (density of vegetative and flowering individuals); (g) Senecio carpathicus in its sward habitat (density of vegetative and flowering individuals); (h) Polygonum viviparum in its sward habitat in the Chornohora Mts (density of vegetative and flowering individuals); (i) Loiseleuria procumbens in its dwarf-shrub heath habitat (density of shoots). Location and size of plots are described in Table 1. Error bars are $90 \%$ confidence intervals for a corresponding sample size. 
Table 1. Location and size of plots for monitoring populations of the studied species.

\begin{tabular}{|c|c|c|c|}
\hline Species & Habitat Type & Location & Size of Plots \\
\hline $\begin{array}{l}\text { Saxifraga carpatica, } \\
\text { Veronica alpina }\end{array}$ & snowbed & $\begin{array}{l}\text { Vorozheskyi cirque NE, the } \\
\text { Svydovets Mts, } 1565 \mathrm{~m} \text { a.s.1. }\end{array}$ & $10 \times 5 \mathrm{~m}(501 \times 1 \mathrm{~m}$ quadrats $)$ \\
\hline Cardaminopsis neglecta & scree & $\begin{array}{c}\text { Mt. Brebeneskul NE, the } \\
\text { Chornohora Mts, } 1890 \text { m a.s.l. }\end{array}$ & $5 \times 5 \mathrm{~m}(251 \times 1 \mathrm{~m}$ quadrats $)$ \\
\hline Erigeron atticus * & rock & $\begin{array}{l}\text { Mt. Dantsyr E, the Chornohora } \\
\text { Mts, } 1530 \text { m a.s.l. }\end{array}$ & $5 \times 1 \mathrm{~m}(200.5 \times 0.5 \mathrm{~m}$ quadrats $)$ \\
\hline Veronica bellidioides * & ridge & $\begin{array}{l}\text { Mt. Pip Ivan NE, the Marmarosh } \\
\text { Mts, } 1930 \text { m a.s.l. }\end{array}$ & $10 \times 2 \mathrm{~m}(201 \times 1 \mathrm{~m}$ quadrats $)$ \\
\hline $\begin{array}{l}\text { Swertia perennis subsp. } \\
\text { alpestris }\end{array}$ & mire & $\begin{array}{l}\text { Mt. Petros S, the Chornohora Mts, } \\
1500 \mathrm{~m} \text { a.s.l. }\end{array}$ & $\begin{array}{c}12.5 \times 0.5 \mathrm{~m}(250.5 \times 0.5 \mathrm{~m} \text { quadrats } \\
\text { for adult individuals and } 250.2 \times 0.2 \mathrm{~m} \\
\text { quadrats for seedlings })\end{array}$ \\
\hline Achillea lingulata & $\begin{array}{l}\text { tall-herb } \\
\text { community }\end{array}$ & $\begin{array}{l}\text { Turkulska Polonina SW, the } \\
\text { Chornohora Mts, } 1820 \text { m a.s.l. }\end{array}$ & $20 \times 1 \mathrm{~m}(201 \times 1 \mathrm{~m}$ quadrats $)$ \\
\hline Senecio carpathicus & sward & $\begin{array}{l}\text { Mt. Rebra SW, the Chornohora } \\
\text { Mts, } 1900 \text { m a.s.l. }\end{array}$ & $20 \times 1 \mathrm{~m}(201 \times 1$ m quadrats $)$ \\
\hline Polygonum viviparum & sward & $\begin{array}{l}\text { Mt. Turkul W, the Chornohora } \\
\text { Mts, } 1900 \text { m a.s.l. }\end{array}$ & $20 \times 1 \mathrm{~m}(201 \times 1$ m quadrats $)$ \\
\hline Loiseleuria procumbens & $\begin{array}{l}\text { dwarf-shrub } \\
\text { heath }\end{array}$ & $\begin{array}{l}\text { Mt. Lysyna N, the Chornohora } \\
\text { Mts, } 1805 \mathrm{~m} \text { a.s.l. }\end{array}$ & $10 \times 0.5 \mathrm{~m}(200.5 \times 0.5 \mathrm{~m}$ quadrats $)$ \\
\hline
\end{tabular}

* All individuals were censused.

The study plots were established either in historically undisturbed sites or in the localities where grazing had stopped already in the 1970s, i.e., recent successional shifts have been caused mostly by climate change rather than by post-anthropogenic recovery.

Spatial shifts of the boundary between the patches of Salix herbacea and Poa granitica subsp. disparilis in a shrinking snowbed habitat in the Chornohora Mts (1890 $\mathrm{m}$ a.s.l.) were monitored from 2011 to 2017 by means of marker pins using mapping and photopoint method [23].

Resurveys of the studied populations were performed on similar calendar dates.

The role of gaps in vegetation in the species' recruitment was defined by observations of occurrence of their seedlings in the open microsites.

Nomenclature for vascular plants follows Mirek et al. [24], and Malynovski and Kricsfalusy [25] for phytosociological units.

\section{Results}

Dynamics of the snow cover, summer air temperature, and precipitation in the Chornohora Mts, Ukrainian Carpathians (Figure 2) reveals distinct temporal trends of these variables.

In a snowbed in the Svydovets Mts that has gradually shrunk, a significant decline was marked in the populations of Saxifraga carpatica and Veronica alpina (Figure 3a). Monitoring of the boundary between patches of a prostrate chionophylous dwarf shrub Salix herbacea and a tussock grass Poa granitica subsp. disparilis showed that the latter species has advanced for $4.1 \pm 0.4 \mathrm{~cm}$ in 6 years (i.e., about $7 \mathrm{~mm}$ per year) in a small shrinking snowbed habitat in the Chornohora Mts.

The changes in the scree-dwellers are illustrated by population dynamics of a case study glareophytic species Cardaminopsis neglecta in its alpine scree habitat in the Chornohora Mts (Figure 3b). This once large population has shrunk considerably over the last century [10] and, despite some fluctuations, has been gradually declining during the 15-year period of its ongoing monitoring.

The dynamics of rare petrophytous species in their rocky localities was monitored on a small population of a rare high-mountain species Erigeron atticus on rock ledges in the Chornohora Mts. The monitoring showed its decline and eventual extinction that was confirmed in 2010 (Figure 3c). The dramatic decrease of seedlings of E. atticus results from the rapid loss of barren microsites suitable for their recruitment due to the massive spread of Pinus mugo and Juniperus communis subsp. alpina. 
The vulnerability of the most specialized cryophilic species in the ridge habitats demonstrates that the population of Veronica bellidioides in the Marmarosh Mts (Figure 3d) is prone to decrease and extinction.

Hygrophytous species which inhabit mires and springs are represented by the population of Swertia perennis subsp. alpestris on the calcium-rich fen in the Chornohora Mts. Rapid decrease in its density has been monitored for the last 19 years (Figure 3e). The same declining trend concerns Pedicularis oederi that now remains only in the vicinity of Mt. Brebeneskul in the Chornohora Mts where it forms a metapopulation, which includes a series of local populations. Some of them, especially those confined to springs, are very unstable because their microhabitats tend to dry up in summer due to climate change. The number of spring-related local populations of $P$. oederi has reduced from 7 to 3 since their first assessment in 1997 [26]. However, local populations confined to peat bogs proved to be more stable and less vulnerable.

Despite the above facts of the negative dynamics of the rare alpine species in the Ukrainian Carpathians, there are also positive examples concerning the size of their populations in the high-mountain zone. This particularly refers to Achillea lingulata, a case study species which represents tall-herb communities and exhibits a marked increase in its density (especially of flowering individuals) in the habitat located at the edge of the rocks in the Chornohora Mts (Figure 3f).

Positive dynamics have also been demonstrated by some rare alpine species that occur in the sward habitats. For instance, the monitored population of Senecio carpathicus in the Chornohora Mts has been showing a considerable increase during the last decade (Figure 3g). Despite its low stature, this species is highly competitive even in rather dense low-grass communities (mostly of the alliance Festuco saxatilis-Seslerion bielzii) and does not need gaps for recruitment. However, other species that can be characterized as gap-demanding (for instance, Polygonum viviparum, Saxifraga adscendens, Thlaspi kovatsii) show their highest density on patches with sparser vegetation cover. One of them, Polygonum viviparum exhibits some decrease in its alpine locality (Figure $3 \mathrm{~h}$ ) because of progressive crowding in its grassy habitat during the succession.

The changes in rare species occurring in ericaceous dwarf-shrub heaths were tracked in a case study of a rare alpine population for the Ukrainian Carpathians alpine cushion dwarf shrub Loiseleuria procumbens, which forms dense mats within the association Loiseleurio-Cetrarietum. During the decade of monitoring, its density on the study plot had grown by about $25 \%$, mostly due to covering of the gaps between clones (Figure $3 \mathrm{i}$ ). The gaps in the mats of other ericaceous dwarf-shrubs are crucial for the recruitment of some rare herbaceous species. For instance, it was found that barren loci resulting from the frost damage to the mats of Vaccinium myrtillus and V. vitis-idaea facilitate the recruitment of Gentiana punctata. Thus, in 2013, as much as $84.7 \%$ of immature individuals in the monitored population of G. punctata in the community Vaccinietum myrtilii in the subalpine zone of the Chornohora Mts were restricted to such loci, where their density ranged within 3-8 individuals per $\mathrm{m}^{2}$.

\section{Discussion}

The trends in the analyzed climatic parameters (Figure 2) are confirmed by the comprehensive overview of the dynamics of the main meteorological climatic variables during the last decades all over the Carpathian region [27] referring to climate change. This implies successional shifts in the alpine ecosystems and populations of oreophytic plant species. Thus, the habitats characterized by massive snowpack (i.e., snowbeds and screes) are doomed to shrinkage due to the decrease in snow cover (Figure 2a). This entails the decline of the rare species confined to such habitats. The same concerns affect some hygrophytous species. Despite the increasing trend in annual precipitation total, the summer precipitation amount has markedly dropped during last 14 years (Figure 2c). Redistribution of precipitation in the region at the expense of the summer season was also noticed by Balabukh and Lukianets [28]. Because of changes in hydrological and thermal conditions, i.e., the rise of temperature (Figure 2b) and, consequently, evaporation, as well as scarcer summer precipitation, 
the habitats of the listed above rare hygrophytous species are prone to drying up and shrinkage, which explains negative dynamics of their populations.

Stenotopic cold-demanding species typical of snowbeds, screes and ridges proved to be very vulnerable to climate changes. Some of them belong to specialized life forms, for instance, cushions that accumulate heat $[15,29]$, e.g., Saxifraga bryoides and S. oppositifolia. Physiological and morphological adaptations of the cold-specialized species, particularly in the leaves, enable efficient gas exchange in cold environment [15,30], but are disadvantageous in the warmer climate and cause overheating and withering of plants that cannot tolerate the increase of temperature above certain levels. Therefore, such cold specialists are vulnerable to warming, particularly the declining cryophilic species restricted to the uppermost barren ridge habitats. Such wind-swept ridges do not accumulate much snow that contributes to harsh thermal conditions which can be tolerated only by highly adapted plants (such as Luzula spicata, Saxifraga bryoides, Veronica bellidioides). In contrast to the other types of habitats, the ridge localities are rather resistant to the climate-induced encroachment of advancing plants; therefore, the shrinkage of vegetation-free patches is not evident there. Thus, the decrease of the cryophilic species in these habitats can be explained mostly by the direct effect of rising temperature rather than by unfavorable phytosociological shifts. Apparently, due to climate change, these cryophiles (whose thermal optimum corresponds to the higher mountains) have reached the limit of their tolerance during summer periods when increasing maximum temperatures (Figure $2 b$ ) become the main adverse factor [31]. As stated by Dahl [15], it is maximum summer temperature that shapes the distribution of cold-demanding species at the trailing edge. The declining trend of the only existing in the Ukrainian Carpathians population of a cold-demanding species Veronica bellidioides (Figure 3d) proves that it is at the brink of extinction in the region [32] which is in line with the data from the Sudeten Mts [33].

By contrast, more thermophilic rare tall herbs would benefit from warming that enables their establishment at higher elevations due to longer snowless periods. Tall-herb communities have been expanding lately in the Carpathians [34,35].

The important driving factor that affects the rare species is the climate-induced change in vegetation, which is secondary to warming as its consequence [36]. This factor should be considered separately because its impact involves shifts in interspecific competition in alpine ecosystems. Thus, sparsely vegetated snowbed, scree, or petrophytous habitats of many low-competitive rare alpine plants undergo gradual overgrowth with more thermophilic and rather competitive tussock-forming graminoids, shrubs, or elfin woodland. This may cause shrinkage or even loss of some of their habitats and, consequently, extinction of populations of the rare species which occur there as it happened to the monitored population of Erigeron atticus (Figure 3c).

In addition to climate change, present successional processes in the high-mountain zone have a marked post-anthropogenic background resulting from the abandonment of traditional land-use, mostly grazing, which once was very common in the region. These two drivers-climate change and restoration of natural vegetation-usually act simultaneously and synergistically. However, the effect of land-use abandonment on vegetation was most evident during the first decades after cessation of grazing, i.e., in the 1970-80s, while climate change has been gaining in importance lately, especially in the alpine communities where the climatic component is most crucial in shaping the vegetation [2]. Likewise, the latter factor is more evident in the habitats with scarce vegetation (e.g., ridges, snowbeds, screes), while the consequences of the previous land-use are better traceable in crowded communities (dwarf-shrub heaths, tall-herb patches, swards).

Alpine species are mostly small and low-statured, which is caused by adaptation to the harsh environment but makes them vulnerable and prone to suppression by taller or more expansive ingressing plants. For instance, Salix herbacea, a prostrate dwarf shrub adapted to short growth seasons ends its aerial development and drops leaves already in late August-early September in its studied shrinking snowbed habitat in the Chornohora Mts. However, due to warming, the temperature still remains rather high there (mainly over $+5^{\circ} \mathrm{C}$ ) in September and partially in October. That enables advancing graminoids (Festuca picta, Luzula alpinopilosa, Poa granitica subsp. disparilis) to take advantage 
of the prolonged growth period and succeed in the competition with $S$. herbacea that results in gradual displacement of the latter species. This example concerns clonal plants which prevail in the high-mountain zone for their better persistence in the alpine environment [13,37].

Infrequent in the alpine flora aclonal plants [38], which are capable only of seed reproduction, are still more vulnerable, especially short-lived species (Cardaminopsis neglecta, Oxyria digyna, Pedicularis oederi, P. verticillata, Saxifraga carpatica, S. adscendens). Because flower development, seed yield, and germination, as well as seedling establishment, are susceptible to adverse alpine conditions (frost, desiccation, etc.); their populations undergo significant fluctuations and are unstable. They are very sensitive to vegetation change because most need open sites for seed recruitment; however, such suitable microhabitats tend to shrink due to crowding which has been increasing throughout the succession. The vulnerability of short-lived species was also noticed by Eriksson and Jakobsson [39] and Bekker and Kwak [40], and their susceptibility to climate change in the alpine ecosystems was claimed by Cannone et al. [13].

Vegetation-free microsites are crucial for the seed recruitment of many alpine species including long-lived clonal plants, e.g., Dryas octopetala, Salix herbacea [41], and Gentiana punctata [42]. While the persistence of their established clones is provided by vegetative growth, the seed reproduction enables their spread due to encroachment into open uninhabited patches. Such sites become colonized by pioneer and early-successional cold-dwelling species (Cardaminopsis neglecta, Cerastium cerastoides, Saxifraga carpatica, Veronica alpina) on the screes, late-melting snowbeds or poorly vegetated rocks. As primary climatogenic succession leads to gradual crowding, the area of microsites suitable for recruitment of such species has been diminishing in the course of warming.

One of the causes of the displacement of many rare low-statured alpine species is the expansion of ericaceous dwarf-shrub heaths throughout the alpine zone of the European mountains which has been widely acknowledged lately [11,43]. This process is contributed to both by climate change and by land abandonment, and involves upward advance and active spread of the Vaccinium species ( $V$. myrtillus, V. gaultherioides, V. vitis-idaea), more common at the lower elevations. They form dense mats that, however, are vulnerable to severe frost damage which has been happening more frequently lately because of the climate-driven decrease in snow depth [44]. Frost-induced vacated gaps in closed heath or grassland vegetation (sometimes up to a few $\mathrm{m}^{2}$ ) provide suitable microsites for the seedling establishment of some rare species with various thermal requirements-both restricted to the upper elevations (Doronicum stiriacum, Polygonum viviparum, Salix retusa) or occurring in a wider altitudinal range (Gentiana lutea, G. punctata). Such disturbances are also favorable for clonal proliferation of some low-statured poorly competitive rare species (Diphasiastrum alpinum, Loiseleuria procumbens, Selaginella selaginoides).

Unlike the mentioned above Vaccinium species, another ericaceous dwarf shrub, Loiseleuria procumbens, benefits from the decrease in snow cover [44]. This frost-tolerant evergreen cushion plant which inhabits convex windswept snowless sites exhibits positive dynamics in the alpine habitats (Figure 3i) due to the replacement of its frost-susceptible competitors. However, distributional limit of L. procumbens in the Chornohora Mts has shifted upward considerably since late 19th century at the expense of the lowermost subalpine populations [10].

\section{Conclusions}

Climate change affects the alpine species in two ways: (i) by the direct influence (positive or negative) on their viability; (ii) through alterations in phytosociological relations in the course of the climate-induced succession of vegetation in their localities. These factors are often synergetic, and their effects are hardly distinguishable from each other. Apparently, the denser the vegetation cover, the bigger is the role of interspecific competition. The response of a particular species to warming depends on its ecological (especially thermal) requirements, competitiveness, and position of a habitat within the altitudinal range of the species distribution (upper, optimum, or lower). Consequently, 
the declining response of the most cryophilic species at the lower (rear) edge of their distribution would totally differ from the spreading dynamics of more thermophilic plants at their upper (leading) limit.

Most vulnerable are the species is confined to the types of habitats that tend to shrink, i.e., snowbeds, alpine screes, barren rocks; uppermost parts of the highest ridges with the harshest climatic conditions and hygrophytous sites (mires and streams). In the Ukrainian Carpathians, the area of the habitats suitable for cold-demanding species is very limited, and they are prone to decline and extinction. However, populations of some other rare species, particularly rather thermophilic tall herbs, have increased lately.

An important factor that limits the viability of populations of many studied species is the availability of open microsites suitable for their seedling recruitment, which tend to reduce in the course of succession. On the other hand, the climate-induced decrease of snow cover often causes frost damage to vegetation that provides gaps available for recruitment of many rare species.

Climate change has a considerable impact on the abundance and distribution of species in the Ukrainian Carpathians, particularly in their high-mountain zone. Decline and extinction of rare cold-demanding species pose a significant threat of biodiversity loss in the region, i.e., on the north-eastern edge of distribution of many alpine species in Central Europe. This especially refers to narrow-range species, for instance, Cardaminopsis neglecta (Figure 3b).

Until lately, the impact of climate change on the population dynamics of threatened species has been largely underestimated in the conservation literature concerning the Carpathian region, particularly in the Red Data Book of Ukraine [18]. Apparently, the role of that factor should be fundamentally reconsidered.

Acknowledgments: The research was supported by the Ministry of Education and Science of Ukraine (grant 0116U001546) and the State Fund for Fundamental Research (grant F76/81-2017).

Conflicts of Interest: The author declares no conflict of interest.

\section{References}

1. Hof, C.; Levinsky, I.; Araújo, M.B.; Rahbek, C. Rethinking species' ability to cope with rapid climate change. Glob. Chang. Biol. 2011, 17, 2987-2990. [CrossRef]

2. IPCC. Climate Change 2014: Synthesis Report. Contribution of Working Groups I, II and III to the Fifth Assessment Report of the Intergovernmental Panel on Climate Change; Core Writing Team, Pachauri, R., Meyer, L., Eds.; IPCC: Geneva, Switzerland, 2015; ISBN 978-92-9169-143-2.

3. Pauli, H.; Gottfried, M.; Reiter, K.; Grabherr, G. High mountain summits as sensitive indicators of climate change effects on vegetation patterns: The "multi summit-approach" of GLORIA (Global Observation Research Initiative in Alpine Environments). In Global Change and Protected Areas; Visconti, G., Beniston, M., Iannorelli, E.D., Barba, D., Eds.; Kluwer Academic Publishers: Dordrecht, The Netherlands, 2001; pp. 45-51, ISBN 978-0-306-48051-5.

4. Kruhlov, I. Delimitatsiya, metryzatsiya ta klasyfikatsiya morfohennykh ekorehioniv Ukrayins'kykh Karpat. Ukr. Geogr. J. 2008, 3, 59-68.

5. Mkrtchian, A.; Svidzinska, D. Modeling the location of natural cold-limited treeline and alpine meadow habitats in Ukrainian Carpathians. In Forum Carpaticum 2014: Local Responses to Global Challenges; Conference Abstracts; Kruhlov, I., Prots, B., Eds.; Ukrayinskyy Bestseler: Lviv, Ukraine, 2014; pp. 102-103.

6. Landolt, E. Ökologische Zeigerwerte zur Schweizer Flora. In Veröffentlichungen des Geobotanischen; Institutes der ETH: Zürich, Switzerland, 1977; Volume 64, pp. 1-208. [CrossRef]

7. Ellenberg, H.; Weber, H.E.; Düll, R.; Wirth, V.; Werner, W.; Paulissen, D. Zeigerwerte von Pflanzen in Mitteleuropa, 2nd ed.; Goltze: Göttingen, Germany, 1992.

8. Zarzycki, K.; Trzcińska-Tacik, H.; Różański, W.; Szelag, Z.; Wołek, J.; Korzeniak, U. Ecological Indicator Values of Vascular Plants of Poland; W. Szafer Institute of Botany, Polish Academy of Sciences: Kraków, Poland, 2002; ISBN 9788385444954.

9. Pauli, H.; Gottfried, M.; Grabherr, G. Effects of climate change on the alpine and nival vegetation of the Alps. J. Mt. Ecol. 2003, 7, 9-12. 
10. Kobiv, Y. Response of rare alpine plant species to climate change in the Ukrainian Carpathians. Folia Geobot. 2017, 52, 217-226. [CrossRef]

11. Klanderud, K.; Birks, H.J.B. Recent increases in species richness and shifts in altitudinal distributions of Norwegian mountain plants. Holocene 2003, 13, 1-6. [CrossRef]

12. Pauli, H.; Gottfried, M.; Reiter, K.; Klettner, C.; Grabherr, G. Signals of range expansions and contractions of vascular plants in the high Alps: Observations (1994-2004) at the GLORIA master site Schrankogel, Tyrol, Austria. Glob. Chang. Biol. 2007, 13, 147-156. [CrossRef]

13. Cannone, N.; Diolaiuti, G.; Guglielmin, M.; Smiraglia, C. Accelerating climate change impacts on alpine glacier forefield ecosystems in the European Alps. Ecol. Appl. 2008, 18, 637-648. [CrossRef] [PubMed]

14. Weather Archive in Pozhezhevskaya. Available online: http://rp5.ua/Weather_archive_in_Pozhezhevskaya (accessed on 3 October 2017).

15. Dahl, E. The Phytogeography of Northern Europe: British Isles, Fennoscandia, and Adjacent Areas; Cambridge University Press: Cambridge, UK, 1998; ISBN 9780521383585.

16. Körner, C. Alpine Plant Life: Functional Plant Ecology of High Mountain Ecosystems, 2nd ed.; Springer: Berlin/Heidelberg, Germany; New York, NY, USA, 2003; ISBN 978-3-642-18970-8.

17. Malinovski, K.; Tsaryk, Y.; Kyyak, V.; Nesteruk, Y. Ridkisni, Endemichni, Reliktovi ta Pohranychno-arealni vydy Roslyn Ukrayins'kykh Karpat; Liga-Press: Lviv, Ukraine, 2002; ISBN 966-8293-03-4.

18. Didukh, Y.P. (Ed.) Chervona knyha Ukrayiny: Roslynnyi svit; Globalconsulting: Kyiv, Ukraine, 2009; ISBN 978-966-97059-1-4.

19. Nagy, L.; Grabherr, G.; Körner, C.; Thompson, D.B.A. (Eds.) Alpine Biodiversity in Europe; Springer: Berlin, Germany, 2003; ISBN 978-3-642-62387-5.

20. Keller, F.; Goyette, S.; Beniston, M. Sensitivity analysis of snow cover to climate change scenarios and their impact on plant habitats in alpine terrain. Clim. Chang. 2005, 72, 299-319. [CrossRef]

21. Greig-Smith, P. Quantitative Plant Ecology, 3rd ed.; University of California Press: Berkeley, CA, USA; Los Angeles, CA, USA, 1992; ISBN 978-0520050808.

22. Harper, J.L. Population Biology of Plants; Academic Press: New York, NY, USA; London, UK, 1977; ISBN 978-1932846249.

23. Elzinga, C.L.; Salzer, D.W.; Willoughby, J.W.; Gibbs, J.P. Monitoring Plant and Animal Populations: A Handbook for Field Biologists; Wiley-Blackwell: Oxford, UK, 2001; ISBN 978-0-632-04442-9.

24. Mirek, Z.; Piękoś-Mirkowa, H.; Zając, A.; Zając, M. Flowering Plants and Pteridophytes of Poland. A Checklist; W. Szafer Institute of Botany, Polish Academy of Sciences: Kraków, Poland, 2002; ISBN 978-8385444831.

25. Malynovski, K.; Kricsfalusy, V. Plant Communities of the Ukrainian Carpathian Highlands; Karpatska Vezha: Uzhgorod, Ukraine, 2002; ISBN 966-8269-05-5.

26. Kobiv, Y.; Nesteruk, Y. Pedicularis oederi (Scrophulariaceae) in the Chornohora Mts (Ukrainian Carpathians): Distribution, biology, ecology and threat. Pol. Bot. J. 2001, 46, 241-250.

27. Spinoni, J.; Szalai, S.; Szentimrey, T.; Lakatos, M.; Bihari, Z.; Nagy, A.; Németh, Á.; Kovács, T.; Mihic, D.; Dacic, M.; et al. Climate of the Carpathian Region in the period 1961-2010: Climatologies and trends of 10 variables. Int. J. Climatol. 2015, 35, 1322-1341. [CrossRef]

28. Balabukh, V.O.; Lukianets, O.I. Zmina klimatu ta yoho naslidky u Rakhivskomu rayoni Zakarpatskoyi oblasti. Hydrol. Hydrochem. Hydroecol. 2015, 37, 132-148.

29. Larcher, W.; Wagner, J. Temperatures in the life zones of the Tyrolean Alps. Sitzungsber. Abt. I 2010, $213,31-51$. [CrossRef]

30. Beerling, D.J. Biological flora of the British Isles: Salix herbacea L. J. Ecol. 1998, 86, 872-895. [CrossRef]

31. Kobiv, Y. Luzula spicata (Juncaceae) in the Ukrainian Carpathians: On the brink of extinction. Ukr. Bot. J. 2018, 75, 70-76. [CrossRef]

32. Kobiv, Y.; Prokopiv, A.; Nachychko, V.; Borsukevych, L.; Helesh, M. Distribution and population status of rare plant species in the Marmarosh Mountains (Ukrainian Carpathians). Ukr. Bot. J. 2017, 74, 163-176. [CrossRef]

33. Szczęśniak, E.; Krukowski, M.; Malicki, M. Pojawy i stopień zagrożenia Veronica bellidioides (Scrophulariaceae) w Polsce. Fragm. Florist. Geobot. Polonica 2011, 18, 3-9.

34. Kobiv, Y. Response of rare plant species to current changes of vegetation in the Ukrainian Carpathians. In Forum Carpaticum 2014: Local Responses to Global Challenges; Conference Abstracts; Ukrayinskyy Bestseler: Lviv, Ukraine, 2014; pp. 58-60. 
35. Czortek, P.; Kapfer, J.; Delimat, A.; Eycott, A.E.; Grytnes, J.-A.; Orczewska, A.; Ratyńska, H.; Zięba, A.; Jaroszewicz, B. Plant species composition shifts in the Tatra Mts as a response to environmental change: A resurvey study after 90 years. Folia Geobot. 2018, 52,1-16. [CrossRef]

36. Nagy, L. European high mountain (alpine) vegetation and its suitability for indicating climate change impacts. Proc. R. Ir. Acad. B 2006, 106, 335-341. [CrossRef]

37. Klimeš, L.; Klimešová, J.; Hendriks, R.; van Groenendael, J. Clonal plant architecture: A comparative analysis of form and function. In The Ecology and Evolution of Clonal Plants; de Kroon, H., van Groenendael, J., Eds.; Backhuys Publishers: Leiden, The Netherlands, 1997; pp. 1-29, ISBN 9789073348738.

38. Grabherr, G.; Gottfried, M.; Pauli, H. Climate change impacts in alpine environments. Geogr. Compass 2010, 4, 1133-1153. [CrossRef]

39. Eriksson, O.; Jakobsson, A. Abundance, distribution and life histories of grassland plants: A comparative study of 81 species. J. Ecol. 1998, 86, 922-933. [CrossRef]

40. Bekker, R.M.; Kwak, M.M. Life history traits as predictors of plant rarity, with particular reference to hemiparasitic Orobanchaceae. Folia Geobot. 2005, 40, 231-242. [CrossRef]

41. Graae, B.; Ejrnæs, R.; Lang, S.; Meineri, E.; Ibarra, P.; Bruun, H. Strong microsite control of seedling recruitment in tundra. Oecologia 2011, 166, 565-576. [CrossRef] [PubMed]

42. Kobiv, Y. Rol' prydatnykh mikrooselyshch u samovidnovlenni populyatsiy ridkisnykh vydiv roslyn Ukrayins'kykh Karpat. Ukr. Bot. J. 2012, 69, 178-189.

43. Cannone, N.; Sgorbati, S.; Guglielmin, M. Unexpected impacts of climate change on alpine vegetation. Front. Ecol. Environ. 2007, 5, 360-364. [CrossRef]

44. Wipf, S.; Stoeckli, V.; Bebi, P. Winter climate change in alpine tundra: Plant responses to changes in snow depth and snowmelt timing. Clim. Chang. 2009, 94, 105-121. [CrossRef]

(C) 2018 by the author. Licensee MDPI, Basel, Switzerland. This article is an open access article distributed under the terms and conditions of the Creative Commons Attribution (CC BY) license (http:/ / creativecommons.org/licenses/by/4.0/). 